\title{
Persistence of HPV after radio-chemotherapy in locally advanced cervical cancer
}

\author{
GIANNA BADARACCO ${ }^{1}$, ANTONELLA SAVARESE ${ }^{2}$, ADRIANA MICHELI ${ }^{3}$, CONSUELO RIZZO $^{1}$, \\ FRANCESCA PAOLINI $^{1}$, MARIANTONIA CAROSI ${ }^{5}$, GIUSEPPE CUTILLO ${ }^{4}$, \\ ENRICO VIZZA ${ }^{4}$, GIORGIO ARCANGELI ${ }^{3}$ and ALDO VENUTI ${ }^{1}$
}

Divisions of Virology ${ }^{1}$, Medical Oncology ${ }^{2}$, Radiotherapy ${ }^{3}$, Gynecology $^{4}$, Pathology $^{5}$, Regina Elena Cancer Institute, Rome, Italy

Received May 26, 2009; Accepted July 20, 2009

DOI: 10.3892/or_00000737

\begin{abstract}
A causal association of high risk HPV persistent infections with cervical cancer is firmly established by epidemiological and experimental evidence. Since HPV is considered a necessary factor for cervix carcinoma development and disease severity, the HPV DNA persistence may represent an indicator of both therapy effectiveness and risk of recurrence. The presence of HPV in locally advanced cervical carcinoma was analysed at the beginning of therapy, shortly after treatment and during follow-up, in 18 patients with cervix carcinoma treated by radio/chemotherapy. Persistence of HPV DNA sequences was revealed in $62.5 \%$ (10/16) of HPV positive patients, in which the HPV type and its physical status were exactly the same as at the onset of therapy, even many years after surgery. Interestingly, in two patients the HPV18 sequence analysis detected the same point mutations in the samples before and after the chemotherapy, and during the follow-up. HPV DNA clearance was associated with a better patient outcome because the majority of the HPV cleared women showed a complete response (6/6), no disease recurrence (4/6), and are still alive. Nevertheless, statistically significant association was seen only with complete responses versus partial or no responses. In conclusion, we demonstrated that HPV DNA positive tumour cells might persist for years in the genital epithelia, even after the surgical removal of the cervix and that HPV DNA detection after therapy is a valid and significant $(p=0.03)$ tool to assess the efficacy of the treatment.
\end{abstract}

\section{Introduction}

Cervical cancer is one of the most common cancers among women worldwide. Every year, about 490,000 new cases are

Correspondence to: Dr Aldo Venuti, Lab. Virology, CRS Regina Elena Cancer Institute, via Messi d'Oro 156, 00158 Rome, Italy E-mail: venuti@ifo.it

Key words: HPV, cervical cancer, therapy, persistence, follow-up diagnosed worldwide, and more than half of the affected women will die of the disease (1). In areas of the world where most women do not have access to regular gynaecological care and screening, cervical cancer is second only to breast cancer as a cancer-related cause of death.

Persistent infections with a high risk carcinogenic HPV are found in all cases of cervical cancer and their causal association with these tumours is firmly established by epidemiological and experimental evidence (2). Virtually, all cervical cancers (99\%) contain high risk HPVs, most commonly HPV16, 18, 31 and 45 types (3).

Radiation therapy along with surgery is considered the most effective treatment for cervical cancer. Nevertheless, the treatment is often unsuccessful for the presence of local recurrence (3-8\% for stage I to $45 \%$ for stage III) (4) and postirradiation adjuvant hysterectomy or chemotherapy could be recommended (5). Recent clinical trials have demonstrated that concurrent chemo-radiotherapy, where Cisplatinumbased regimen is administered concomitantly with irradiation, may be considered the standard treatment for locally advanced disease (6-8). Although increasing interest has been addressed to this tool, the role of neoadjuvant regimens on locally advanced cervical carcinoma (LACC) in improving tumour resectability and prognosis is still under investigation. Moreover, pre-operative therapy might also represent a feasible clinical model for investigating changes induced in the biological features of cancer.

After therapy, persistence of HPV has been demonstrated in a range of $20-50 \%$ of patients affected by different premalignant and malignant lesions, often associated with recurrence (9-11). Since HPV is considered a necessary factor for cervix carcinoma development and disease severity, the HPV DNA persistence may represent an indicator of both therapy effectiveness and risk of recurrence. A possible explanation for HPV persistence might be the presence of the entire HPV genome and/or fragments of it in the degraded tumour cells or in the cell debris produced by the treatment (10). Not only the HPV persistence but also the viral load and the integrated status have been evaluated as prognostic factors $(12,13)$.

Most of the above-mentioned studies were conducted by retrospective analyses or without adequate sampling during 
follow up. Therefore, data regarding the possibility of reinfection or true persistence are lacking and limited data have been collected from patients undergoing surgery at the end of chemo/radiotherapy. Thus, the presence of HPV in locally advanced cervical carcinoma (LACC) patients was analysed at the beginning of the therapy, shortly after the treatment and during the follow-up, to define better the role of HPV persistence in patients with cervix carcinoma after radio/ chemotherapy.

\section{Materials and methods}

Patients and treatments. From February 2002 to August 2003 18 consecutive patients accrued in two different studies for neoadjuvant treatment in LACC were addressed to the HPV evaluation. Tumor staging was assessed by total body TC scan, pelvic and retroperitoneal magnetic resonance and by gynecological examination under anesthesia. Three of the 18 patients were submitted to three courses of neoadjuvant chemotherapy with TIP regimen (Cisplatin $50 \mathrm{mg} / \mathrm{m}^{2}$ on day $1,1 \mathrm{~h}$ infusion; Taxol $175 \mathrm{mg} / \mathrm{m}^{2}$ on day $1,3 \mathrm{~h}$ infusion; Ifosfamide $2500 \mathrm{mg} / \mathrm{m}^{2} /$ day, $4 \mathrm{~h}$ hydratation on days 1 and 2). Fifteen patients were planned to receive 50.4 Gy external beam RT (EBRT) on tumor bed and pelvic lymph nodes plus concomitant CT with cisplatin $5 \mathrm{mg} / \mathrm{m}^{2} /$ day e.v. and 5-fluorouracil $200 \mathrm{mg} / \mathrm{m}^{2} /$ day i.v., day 1-5, for 5-6 weeks. Clinical restaging and clinical response were assessed after therapy by pelvic and retroperitoneal magnetic resonance and by gynecological examination under anesthesia. In operable patients, surgical procedures were performed from 30 to 40 days after the completion of the treatment and consisted in radical hysterectomy plus pelvic lymphadenectomy (PIVER III). The follow-up program for operated patients included pelvic/retroperitoneal magnetic resonance and chest radiogram one month after surgery and every six months for the first two years. Subsequently, a total body TC scan and pelvic ultrasound were planned each six months alternatively for five years. Gynecological examination was performed once a year. Informed consent for the procedures approved by the Institutional ethics committee was obtained from all patients.

Tumor samples. In order to detect HPV status, paraffinembedded samples were available from tumour biopsies collected before the therapy, after therapy or at the surgery, whereas cyto-brushes were performed during the follow-up at the time of gynecological examination.

DNA isolation. Paraffin embedded samples were de-waxed $2 \mathrm{X}$ in xylene for $10 \mathrm{~min}$ and re-hydrated throughout absolute ethanol dilutions. These re-hydrated samples and the exfoliated cells collected into a liquid PreservCyt buffer (Cytyc Corporate, Marlborough, MA, USA) were lysed by proteinase $\mathrm{K}$ digestion and DNA extraction was performed by a QiaAmp DNA kit (Qiagen, Milan, Italy) according to the manufacturer's instructions. The adequacy of the samples and the absence of PCR inhibitors were monitored by preliminary PCR amplifications with primers recognizing the human $B$-globin gene. All the samples gave adequate quality of genomic DNA.
HPV detection and typing. HPV detection was achieved by PCR with the consensus primers MY09/MY11 and GP5+/ GP6+ as already reported (14). Briefly, the PCR conditions were $1.5 \mathrm{mM} \mathrm{MgCl}_{2}$ for $\mathrm{MY09/MY11}$ or $3 \mathrm{mM} \mathrm{MgCl}_{2}$ for GP5+/GP6+, $200 \mu \mathrm{M}$ dNTPs, $0.5 \mu \mathrm{M}$ for each primer and 2.5 U of Platinum Taq DNA Polymerase (Invitrogen, Paisley, $\mathrm{UK}$ ) in a final reaction volume of $50 \mu \mathrm{l}$. PCR products were electrophoresed through $2 \%$ agarose gel and visualised by ethidium bromide staining under ultraviolet light. Typing of the HPV positive samples was performed by automated sequencing of the amplified products (Biogen GeneLab, Rome, Italy). Multiple infections were detected by PCR with the cluster specific HPV primers described by Klaassen et al (15), followed by direct sequencing of the amplified products. Sequence analyses of the positive samples were done using BLAST programme (http://www.ncbi.nlm.nih.gov/BLAST).

Viral load. To determine the number of input cells per test, each sample underwent quantification of the housekeeping B-globin gene. HPV load was expressed as the number of copies per cell assuming that one copy of $\beta$-globin gene corresponds to one cell genome. The same region amplified by GP primers for genotyping was chosen for real-time PCR performed in the I Cycler apparatus (BioRad, Milan, Italy). Viral load was determined with the IQTM SYBR Green Supermix (BioRad) according to the manufacturer's instructions, with a magnesium concentration of $3 \mathrm{mM}$, a primer concentration of $500 \mathrm{nM}$ in a final reaction volume of $25 \mu 1$. A standard curve was constructed with serial dilutions

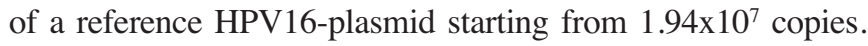
The PCR products underwent a T-melting curve analysis, starting from the annealing temperature up to $95^{\circ} \mathrm{C}$, with increments of $0.5^{\circ} \mathrm{C} / 10 \mathrm{sec}$, in order to verify the specificity of the reaction.

Physical status of viral genome. The integration of HPV16 and HPV18 was detected essentially as already described in detail in a study on HPV physical status in genital tumours (16). Briefly, to distinguish the pure integrated viral forms from the circular form, the integrity of HPV16 or HPV 18 genomes was analysed by amplifications with type specific primers recognizing the almost entire E1 and E2 sequences that are the regions most frequently disrupted or deleted during the viral integration into the cell genome. To determine the concurrent presence of episomal and integrated HPV16 DNA (i.e. mixed forms), samples with an intact E2 sequence were re-amplified in multiplex PCRs with primers for E6 and E2 using a method based on the determination of the relative ratio of E2 to E6 amplified products (E2/E6 ratio) (16).

\section{Results}

Clinical characteristics and treatment outcome of patients. The clinical features of the patients are summarized in Table I. Median age of the patients was 47 years (range 32-75). According to the FIGO classification, 2 out of 18 patients were staged as IIA, $8 / 18$ as IIB and $8 / 18$ as IIIB. Clinical complete response was observed in 12 subjects $(66.7 \%)$, clinical partial response in $4(22.2 \%)$ and stable/progressive disease in $2(11.1 \%)$. Radical surgery (Piver III) at the end of 
Table I. Presence of HPV DNA.

\begin{tabular}{|c|c|c|c|c|c|c|c|c|c|}
\hline & Patient & Stage & Therapy & $\begin{array}{l}\text { San } \\
\text { HPV }\end{array}$ & $\begin{array}{l}\text { nple/ } \\
\text { J type }\end{array}$ & $\begin{array}{l}\text { Viral load } \\
\text { copy/cell }\end{array}$ & $\begin{array}{l}\text { HPV 16/18 } \\
\text { Physical status }\end{array}$ & Treatment response & $\begin{array}{c}\text { Status } \\
\text { Site of recurrence }\end{array}$ \\
\hline 1. & $\mathrm{AM}$ & IIIB & DDP 5-FU/RT & $\begin{array}{l}\text { Pre } \\
\text { Post }\end{array}$ & $\begin{array}{l}16+18 \\
16+18\end{array}$ & nd & $\begin{array}{c}\text { Episomal + } \\
\text { Integrated }\end{array}$ & No response & Deceased $^{\mathrm{a}}$ \\
\hline 2. & $\mathrm{BC}$ & IIB & $\begin{array}{l}\text { DDP 5-FU/RT } \\
+ \text { Surgery }\end{array}$ & $\begin{array}{l}\text { Pre } \\
\text { Post } \\
\text { F-u }\end{array}$ & $\begin{array}{l}16 \\
\text { nd } \\
16\end{array}$ & $\begin{array}{l}62 \\
\text { nd }\end{array}$ & $\begin{array}{c}\text { Episomal + } \\
\text { Integrated }\end{array}$ & Complete response & Alive \\
\hline 3. & BA & IIIB & $\begin{array}{l}\text { DDP 5-FU/RT } \\
+ \text { Surgery }\end{array}$ & $\begin{array}{l}\text { Pre } \\
\text { Post } \\
\text { F-u }\end{array}$ & $\begin{array}{l}16 \\
16 \\
16\end{array}$ & $\begin{array}{c}5100 \\
\text { nd } \\
107\end{array}$ & $\begin{array}{c}\text { Episomal + } \\
\text { Integrated }\end{array}$ & Partial response & $\begin{array}{c}\text { Deceased } \\
\text { Pelvic/brain }\end{array}$ \\
\hline 4. & CAM & IIB & $\begin{array}{l}\text { DDP 5-FU/RT } \\
+ \text { Surgery }\end{array}$ & $\begin{array}{l}\text { Pre } \\
\text { Post }\end{array}$ & $\begin{array}{l}16 \\
\text { neg }\end{array}$ & 525 & Integrated & Complete response & Alive \\
\hline 5. & DRE & IIIB & $\begin{array}{l}\text { DDP 5-FU/RT } \\
+ \text { Surgery }\end{array}$ & $\begin{array}{l}\text { Pre } \\
\text { Post } \\
\text { F-u }\end{array}$ & $\begin{array}{l}\text { HPVX } \\
\text { neg } \\
\text { neg }\end{array}$ & nd & nd & Complete response & Alive \\
\hline 6. & FV & IIB & $\begin{array}{l}\text { DDP 5-FU/RT } \\
+ \text { Surgery }\end{array}$ & $\begin{array}{l}\text { Pre } \\
\text { Post }\end{array}$ & $\begin{array}{l}18+31 \\
18+31\end{array}$ & $\begin{array}{c}580 \\
1630\end{array}$ & Integrated & Complete response & Alive \\
\hline 7. & GF & IIIB & $\begin{array}{l}\text { DDP 5-FU/RT } \\
+ \text { Surgery }\end{array}$ & $\begin{array}{l}\text { Pre } \\
\text { Post } \\
\text { F-u }\end{array}$ & $\begin{array}{l}\text { neg } \\
\text { neg } \\
35\end{array}$ & nd & nd & Complete response & Alive \\
\hline 8. & IT & IIB & $\begin{array}{l}\text { DDP 5-FU/RT } \\
+ \text { Surgery }\end{array}$ & $\begin{array}{l}\text { Pre } \\
\text { Post }\end{array}$ & $\begin{array}{l}16 \\
16\end{array}$ & $\begin{array}{l}26 \\
20\end{array}$ & $\begin{array}{c}\text { Episomal + } \\
\text { Integrated }\end{array}$ & Complete response & Alive \\
\hline 9. & MG & IIIB & $\begin{array}{l}\text { DDP 5-FU/RT } \\
+ \text { Surgery }\end{array}$ & $\begin{array}{l}\text { Pre } \\
\text { Post } \\
\text { F-u }\end{array}$ & $\begin{array}{l}58 \\
\text { neg } \\
\text { neg }\end{array}$ & nd & nd & Complete response & $\begin{array}{l}\text { Deceased } \\
\text { pelvic }\end{array}$ \\
\hline 10 . & $\mathrm{ME}$ & IIB & $\begin{array}{l}\text { DDP 5-FU/RT } \\
+ \text { Surgery }\end{array}$ & $\begin{array}{l}\text { Pre } \\
\text { Post } \\
\text { F-u }\end{array}$ & $\begin{array}{l}16 \\
\text { neg } \\
\text { neg }\end{array}$ & nd & $\begin{array}{c}\text { Episomal + } \\
\text { Integrated }\end{array}$ & Complete response & Alive \\
\hline 11. & MS & IIA & $\begin{array}{l}\text { DDP 5-FU/RT } \\
+ \text { Surgery }\end{array}$ & $\begin{array}{l}\text { Pre } \\
\text { Post } \\
\text { F-u }\end{array}$ & $\begin{array}{l}16 \\
16 \\
16\end{array}$ & $\begin{array}{c}370 \\
100 \\
\text { nd }\end{array}$ & $\begin{array}{c}\text { Episomal + } \\
\text { Integrated }\end{array}$ & Partial response & Alive \\
\hline 12. & PA & IIB & $\begin{array}{l}\text { TIP + } \\
\text { Surgery }\end{array}$ & $\begin{array}{l}\text { Pre } \\
\text { Post }\end{array}$ & $\begin{array}{l}18 \\
18\end{array}$ & $\begin{array}{c}273 \\
94\end{array}$ & Integrated & Complete response & Alive \\
\hline 13. & PM & IIIB & TIP & $\begin{array}{l}\text { Pre } \\
\text { Post }\end{array}$ & $\begin{array}{l}45 \\
45\end{array}$ & $\begin{array}{c}207 \\
\text { nd }\end{array}$ & nd & No response & Deceased $^{\mathrm{a}}$ \\
\hline 14. & RG & IIA & $\begin{array}{l}\text { DDP 5-FU/RT } \\
+ \text { Surgery }\end{array}$ & $\begin{array}{l}\text { Pre } \\
\text { Post }\end{array}$ & $\begin{array}{l}16 \\
\text { neg }\end{array}$ & nd & $\begin{array}{c}\text { Episomal + } \\
\text { Integrated }\end{array}$ & Complete response & $\begin{array}{l}\text { Deceased } \\
\text { pelvic }\end{array}$ \\
\hline 15. & $\mathrm{RM}$ & IIIB & $\begin{array}{l}\text { DDP 5-FU/RT } \\
+ \text { Surgery }\end{array}$ & $\begin{array}{l}\text { Pre } \\
\text { Post } \\
\text { F-u } \\
\text { F-u }\end{array}$ & $\begin{array}{l}18+58 \\
18+58 \\
\text { neg } \\
\text { neg }\end{array}$ & $\begin{array}{c}638 \\
\text { nd }\end{array}$ & Integrated & Complete response & Alive \\
\hline 16. & SA & IIB & $\begin{array}{l}\text { TIP + } \\
\text { Surgery }\end{array}$ & $\begin{array}{l}\text { Pre } \\
\text { Post } \\
\text { F-u }\end{array}$ & $\begin{array}{l}16+18 \\
16+18 \\
16+18 \\
+59+58\end{array}$ & $\begin{array}{c}869 \\
\text { nd } \\
\text { nd }\end{array}$ & Integrated & Partial response & $\begin{array}{l}\text { Alive with } \\
\text { pulmonary } \\
\text { metastases } \\
\text { (resected) }\end{array}$ \\
\hline 17. & TI & IIIB & DDP 5-FU/RT & $\begin{array}{l}\text { Pre } \\
\text { Post }\end{array}$ & $\begin{array}{l}16 \\
16\end{array}$ & $\begin{array}{c}1382 \\
240\end{array}$ & $\begin{array}{c}\text { Episomal + } \\
\text { Integrated }\end{array}$ & Partial response & Alive \\
\hline 18. & VE & IIB & $\begin{array}{l}\text { DDP 5-FU/RT } \\
+ \text { Surgery }\end{array}$ & $\begin{array}{l}\text { Pre } \\
\text { Post } \\
\text { F-u }\end{array}$ & $\begin{array}{l}\text { neg } \\
\text { neg } \\
\text { HPV } \\
\text { (not defi }\end{array}$ & $\begin{array}{r}\text { nd } \\
\text { ined) }\end{array}$ & nd & Complete response & Alive \\
\hline
\end{tabular}

DDP 5-FU, Cisplatin-5-Fluorouracil; Pre, pre-treatment sample; nd, not done; RT, radiotherapy; Post, post-treatment sample; ${ }^{a}$ pelvic progression; TIP, Paclitaxel-Ifosfamide-Cisplatin; F-u, follow-up sample. 


\section{Patient \#12}

CLUSTAL nucleotide sequence alignment \#12PRE ATATGATGCTACCAAATTTAAGCAG 25 \#12POST ATATGATGCTACCAAATTTAAGCAG 25 HPV18 ATATGATGCTACCAAATTTAAGCAG 25 \#12PRE TATAGCAGACATGTTGAGGAATATG 50 \#12POST TATAGCAGACATGTTGAGGAATATG 50 HPV18 TATAGCAGACATGTTGAGGAATATG 50

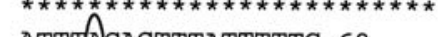
\#12POST ATT ACAGTTTATTTTTC 68 HPV18 ATTIGCAGTTTATTTTTC 68 $* * * *$ ****************

CLUSTAL amino acid sequence alignment \#12PRE VPGQYDATKFKQYSRHVEEYDLQFIF 26 \#12POST VPGQYDATKFKQYSRHVEEYDLQFIF 26 HPV18 VPGQYDATKFKQYSRHVEEYDLQFIF 26

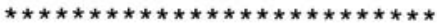

\section{Patient \#16}

CLUSTAL nucleotide sequence alignment \#16PRE ATATGATGCTACCAAATTTAAGCAG 25 \#16POST ATATGATGCTACCAAATTTAAGCAG 25 \#16FW-UP ATATGATGCTACCAAATTTAAGCAG 25 HPV18 ATATGATGCTACCAAATTTAAGCAG 25 $\star * * * * * * * * * * * * * * * * * * * * * * * * *$ \#16Pre tatagcagaogetgtTGaggatatg 50 \#16POST TATAGCAGAOGTGTTGAGGATATG 50 \#16FW-UP TATAGCAGAdGIGTTGAGGATATG 50 HPV18 TATAGCAGACAFGTTGAGGATATG 50 $\star * \star * * * * * * *]_{* \star * * * * * * * * * * * *}$ $\begin{array}{ll}\text { \#16PRE } & \text { ATTTGCAGTTTATTTTTC } 68 \\ \text { \#16POST } & \text { ATTTGCAGTTTATTTTC } 68\end{array}$ \#16FW-UP ATTTGCAGTTTATTTTTC 68 HPV18 ATTTGCAGTTTATTTTTC 68

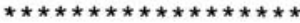

CLUSTAL amino acid sequence alignment \#16PRE VPGQYDATKFKQYSRRVEEYDLQFIF 26 \#16POST VPGQYDATKFKQYSRRVEEYDLQFIF 26 \#16FW-UP VPGQYDATKFKQYSRRVEEYDLQFIF 26 HPV18 VPGQYDATKFKQYSRHVEEYDLQFIF 26

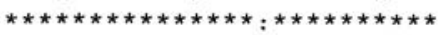

Figure 1. Point mutations in the HPV18 sequence from multiple samples of two patients. For patient no. 12 and no. 16 the nucleotide and the amino acid alignments with the prototype HPV18 (GenBank accession number X05015 and GenPept accession number CAA28671) are reported.*Residue identity, conserved amino acid substitution. The nucleotide transition is circled.

the treatments was performed in 15 subjects who achieved clinical down-staging $(83.3 \%)$. The two patients with no response, one treated with neoadjuvant TIP chemotherapy (progressive disease) and one treated with concomitant chemo-radiotherapy (stable disease), were subsequently addressed to a treatment with concomitant CT-RT to reach 75.4 Gy on tumor bed and 50.4 Gy on pelvis, both obtaining a stable disease. Median overall survival was of 68 months (range 7-86). To date five patients $(27.8 \%$ ) have died of tumour progression (4 locoregional and 1 of locoregional brain metastases). Thirteen women $(72.2 \%)$ are still alive and free from disease. One of them was operated for lung metastases and did not receive any further treatment.

Presence of HPV at the onset of therapy. HPV DNA was detected in 16 out of 18 analysed patients at the onset of therapy $(84 \%)$ (Table I). Among the HPV positive samples,
Table II. FIGO stage by clinical outcome after therapy.

\begin{tabular}{llllll}
\hline & \multicolumn{2}{l}{ Stage II } & \multicolumn{2}{l}{ Stage III } & P-value \\
& No. $\%$ & No. $\%$ & \\
\hline $\begin{array}{l}\text { Response at the end } \\
\text { of therapy }\end{array}$ & & & & & \\
$\quad$ Complete & 8 & 80.0 & 4 & 50.0 & 0.32 \\
$\quad$ Partial/no & 2 & 20.0 & 4 & 50.0 & \\
Disease recurrence & & & & & \\
$\quad$ No. & 8 & 80.0 & 4 & 66.7 & 0.60 \\
$\quad$ Yes & 2 & 20.0 & 2 & 33.3 & \\
Survival & & & & & \\
$\quad$ Dead & 1 & 10.0 & 4 & 50.0 & 0.12 \\
$\quad$ Alive & 9 & 90.0 & 4 & 50.0 & \\
\hline
\end{tabular}

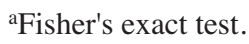

HPV 16 was identified in 10 specimens $(55 \%)$ whereas the HPV 18 and HPV58 in $5(27 \%)$ and $2(11 \%)$ samples, respectively. HPV45, HPV31 and HPVX were detected only once. Multiple infections were revealed in 4 patients $(22 \%)$, the HPV18 was always detected, it was associated with the HPV16 in two patients and with HPV31 and HPV58 in one case each. There was a wide range of HPV DNA concentration measured as copy number per cell (26-5100 copy/cell). About $81 \%$ of the analysed positive samples scored a viral load above 200 copy/cell. Data on physical status were evaluated only for the HPV types 16 and 18 . HPV18 DNA was integrated into the cell genome of all the analysed samples. For the HPV16 the employed technologies allowed us to detect episomal and integrated forms of DNA (mixed forms) within the same sample in 7 out of the 10 HPV16 positive samples.

Presence of HPV at the end of therapy and during follow-up. At the end of therapy the clearance of the HPV DNA sequences was detected in 5 patients, none of them were infected by HPV18 with the exception of one woman (patient no. 15) where the clearance of HPV18 DNA, in a co-infection with HPV58, was achieved during the follow-up, three years after the end of therapy. Persistence of HPV DNA sequences was revealed in 10 out of the $16 \mathrm{HPV}$ positive patients $(62.5 \%)$, in which the HPV type and its physical status were exactly the same as at the onset of therapy. In addition, the presence of new HPV types was detected in patients no. 7 and 18 (Table I).

Sequence analysis of the amplified viral L1 gene showed an identical nucleotide composition of the HPV type in pre-, post-treatment and follow-up samples of each patient. In two patients the comparison of detected sequences with that of HPV18 prototype showed some point mutations in the L1 sequence. In patient no. 12 the nucleotide transition was coding for the same amino acid whereas in the patient no. 16 the point mutation produced a conserved amino acid substitution (Fig. 1). This mutation of the integrated HPV18 genome was still present in the exfoliated cells from residual 
Table III. Clearance or persistence of HPV DNA by clinical outcome after therapy.

\begin{tabular}{|c|c|c|c|c|c|}
\hline & \multicolumn{2}{|c|}{ HPV DNA cleared } & \multicolumn{2}{|c|}{ HPV DNA persisted } & \multirow[b]{2}{*}{ P-value ${ }^{a}$} \\
\hline & No. & $\%$ & No. & $\%$ & \\
\hline \multirow{2}{*}{\multicolumn{6}{|c|}{$\begin{array}{l}\text { Response } \\
\text { at the end of therapy }\end{array}$}} \\
\hline & & & & & \\
\hline Complete & 6 & 100.0 & 4 & 40.0 & 0.03 \\
\hline Partial/no & 0 & 0.0 & 6 & 60.0 & \\
\hline \multicolumn{6}{|c|}{ Disease recurrence } \\
\hline No & 4 & 66.7 & 5 & 62.5 & 1.00 \\
\hline Yes & 2 & 33.3 & 3 & 37.5 & \\
\hline \multicolumn{6}{|l|}{ Survival } \\
\hline Dead & 2 & 33.3 & 3 & 30.0 & 1.00 \\
\hline Alive & 4 & 66.7 & 7 & 70.0 & \\
\hline
\end{tabular}

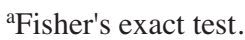

vaginal epithelium collected three years after radical surgery during the follow-up.

In the two patients that were HPV negative at the onset of therapy, the presence of HPV (type 35, patient no. 7 and unknown type, patient no. 18) was detected during the followup after three and four years from the end of the therapy, respectively. Only 2 out of 6 analysed samples scored a viral load over the 200 copy/cell. A strong decrease in the viral load was detected in all patients with the exception of the patient no. 6 in whom a three fold increase was detected (Table I).

Clinical correlations. A complete response after therapy was achieved in 12 patients $(66.6 \%)$ whereas partial response or no response was observed in 4 and 2 patients, respectively. During the follow-up 5 women died, among them two patients were non-responders to the therapy, one patient had a partial response, and two women had a complete response at the end of therapy. FIGO stage at baseline was associated with a poor prognosis as well as to the response to therapy (Table II), even if the differences were not statistically significant ( $\mathrm{p}>0.05$, Fisher's exact test).

HPV DNA clearance was associated with a better patient outcome because all of the HPV cleared women showed a complete response (6/6), 4/6 had no disease recurrence, and they are still alive (Table III). A statistically significant association was seen with complete responses vs. partial/no responses $(\mathrm{p}=0.03$, Fisher's exact test). No significant association of the clinical behaviour was seen with the number of viral genomes (viral load) or the physical status of the HPV.

\section{Discussion}

Several reports suggest that HPV detection may be useful for the prognosis of patient treated for cervical cancer (17-20) and the persistence of the HPV DNA sequence may be predictor for recurrence after therapy (10-12). This crucial point was not well elucidated by previous reports and no data are available to differentiate a true persistence from a reinfection, that is conceivable to occur in follow-up samples collected many years after the end of therapy. Our data showing the presence of HPV16/18 integration in all samples at several year intervals indicate that viral persistence occurs in these patients rather than re-infection. Indeed, integrated viral sequences cannot be infectious and therefore the hypothesis of re-infection by partners appears to be unlikely. This statement is further strengthened by the finding of the same point mutation in the HPV18 genome detected in samples collected three years after therapy. Similar results were reported for HPV induced dysplasia where identical HPV DNA integration loci were detected many years later (21). Therefore, our results confirm this observation and suggest that HPV infected tumour cells may persist in a silent status for several years even in absence of the transitional zone of the cervix, surviving in the residual vaginal epithelia after radical surgery.

Several authors reported from large series of patients that platinum-containing chemotherapy and concomitant radiotherapy can improve overall survival and clinical response in LACC when compared with radiotherapy alone (22-26). Neoadjuvant concomitant (27) or systemic approach (28) was then performed with platinum-based regimen on more selected patients, achieving clinical complete response and operability rate ranging from 50 to $83 \%$ and 48 to $>90 \%$ of cases, respectively. Our patient series consisted in women with poor prognosis because of the locally advanced disease. However, pre-operative chemo- and radiation therapy were very effective in achieving clinical down-staging and long-term survival. In our clinical series, $72 \%$ of women is still alive (only one patient in clinical relapse with resected lung metastases), 15 out of 18 patients underwent surgery (83.3\% operability rate) and 12 patients had a clinical complete response $(66.7 \%)$.

This response was significantly associated with the viral clearance suggesting that the evaluation of the HPV status at 
the end of therapy is a valid tool in assessing the efficacy of the therapy. In addition, HPV typing showed that HPV18 seemed to be more resistant to the therapy suggesting an aggressive behaviour of this virus as already reported for the prognosis of patient treated with surgery in the early stage of cervix cancer $(20,29)$.

Viral load decreased after treatment indicating the possible effect of therapy on the number of infected cells and/or of the viral copies per cell. Although we normalized our data according to the number of cell genomes we cannot obtain information from a single cell, and therefore, it is questionable if the therapy affects the viral copy/number or the total number of infected cells. The increased viral load recorded in a single patient may represent an indicator of the growth of latent tumour cells. A gradual increase of HPV viral load after radiotherapy treatment up to 5 years was already reported in association with recurrence of the disease (12). In contrast, data from viral load in almost exclusively tumour cells did not confirm a clear association with a worse prognosis (30). Indeed in our patient (no. 6) the increased viral load did not correlate with disease recurrence. These conflicting results suggest that the techniques of cell collection and viral load detection as well as the measuring methods may dramatically affect the clinical significance of these data.

In conclusion, we showed that HPV DNA positive tumour cells can persist for years (at least three in patient no. 16) in the genital epithelia even after the surgical removal of the cervix and that the DNA detection after therapy is a valid tool to assess the efficacy of the treatment. Moreover, the HPV positive patients can represent a target population for new immunotherapeutic intervention that is expected to be available against the E7 antigen of oncogenic HPV. Clinical trials have already started with different therapeutic vaccines (31). The possibility to detect HPV clearance up to three years after treatment, as verified in one case (patient no. 15), brings the question on the timing and the time extent of HPV testing during follow-up. More studies have to be performed in order to quantify the cost and benefit in introducing the DNA test in the follow-up of the patients treated for carcinoma of the cervix.

\section{Acknowledgements}

Work partially supported by grants of the Italian Ministry of Health.

\section{References}

1. Parkin DM, Bray F, Ferlay J and Pisani P: Global cancer statistics, 2002. Ca Cancer J Clin 55: 74-108, 2005.

2. IARC Monographs on the evaluation of carcinogenic risks to humans. Human Papillomavirus, vol. 90. International Agency for Research on Cancer, Lyon, 2007.

3. Walboomers JM, Jacobs MV, Manos MM, et al: Human papillomavirus is a necessary cause of invasive cervical cancer worldwide. J Pathol 189: 12-19, 1999.

4. Hunter RD, Cowie VJ, Blair V and Cole MP: A clinical trial of two conceptually different radical radiotherapy treatments in stage III carcinoma of the cervix. Clin Radiol 37: 23-27, 1986.

5. Hosaka M, Watari H, Takeda M, Moriwaki M, Hara Y, Todo Y, Ebina Y and Sakuragi N: Treatment of cervical cancer with adjuvant chemotherapy versus adjuvant radiotherapy after radical hysterectomy and systematic lymphadenectomy. J Obstet Gynaecol Res 34: 552-556, 2008.
6. Fields AL, Anderson PS, Goldberg GL, et al: Mature results of a phase II trial of concomitant Cisplatin/pelvic radiotherapy for locally advanced squamous cell carcinoma of the cervix. Gynecol Oncol 61: 416-422, 1996.

7. Green JA, Kirwan JM, Tiermey JF, et al: Survival and recurrence after concomitant chemotherapy and radiotherapy for cancer of the cervix: a systematic review and meta-analysis. Lancet 358: 781-786, 2001.

8. Rose PG: Chemoradiation for locally advanced cervical cancer: does it help? J Clin Oncol 4: 891-893, 2002.

9. Sedati A, Mariani L, Giovinazzi R, Badaracco G, Venuti A and Atlante G: Prognostic value of infection from human papillomavirus 16 and 18 in the follow-up of patients submitted to conization for cervical intraepithelial neoplasia grade III. Cervix and the Lower Female Genital Tract 9: 252-259, 1991.

10. Nagai Y, Toma T, Moromizato H, et al: Persistence of human papillomavirus infection as a predictor for recurrence in carcinoma of the cervix after radiotherapy. Am J Obstet Gynecol 191: 1907-1913, 2004

11. Nagai Y, Maehama T, Asato T and Kanazawa K: Persistence of human papillomavirus infection after therapeutic conization for CIN 3: is it an alarm for disease recurrence? Gynecol Oncol 79: 294-299, 2000.

12. Singh RK, Maulik S, Mitra S, et al: Human papillomavirus prevalence in postradiotherapy uterine cervical carcinoma patients: correlation with recurrence of the disease. Int J Gynecol Cancer 16: 1048-1054, 2006.

13. Lindel K, de Villiers EM, Burri P, et al: Impact of viral E2-gene status on outcome after radiotherapy for patients with human papillomavirus 16-positive cancer of the uterine cervix. Int J Radiat Oncol Biol Phys 65: 760-765, 2006.

14. Badaracco G, Venuti A, Sedati A and Marcante ML: HPV 16 and HPV18 in genital tumors: Significantly different levels of viral integration and correlation to tumor invasiveness. J Med Virol 67: 574-582, 2002.

15. Klaassen CH, Prinsen CF, de Valk HA, Horrevorts AM, Jeunink MA and Thunnissen FB: DNA microarray format for detection and subtyping of human papillomavirus. J Clin Microbiol 42: 2152-2160, 2004.

16. Yoshinouchi M, Hongo A, Nakamura K, et al: Analysis by multiplex PCR of the physical status of human papillomavirus type 16 DNA in cervical cancers. J Clin Microbiol 37: 3514-3517, 1999.

17. Harima Y, Sawada S, Nagata K, Sougawa M and Ohnishi T: Human papilloma virus (HPV) DNA associated with prognosis of cervical cancer after radiotherapy. Int J Radiat Oncol Biol Phys 52: 1345-1351, 2002.

18. Bachtiary B, Obermair A, Dreier B, et al: Impact of multiple HPV infection on response to treatment and survival in patients receiving radical radiotherapy for cervical cancer. Int J Cancer 102: 237-243, 2002.

19. Huang HJ, Huang SL, Lin CY, et al: Human papillomavirus genotyping by a polymerase chain reaction-based genechip method in cervical carcinoma treated with neoadjuvant chemotherapy plus radical surgery. Int J Gynecol Cancer 14: 639-649, 2004.

20. Wright JD, Li J, Gerhard DS, Zhang Z, et al: Human papillomavirus type and tobacco use as predictors of survival in early stage cervical carcinoma. Gynecol Oncol 98: 84-91, 2005.

21. Vinokurova S, Wentzensen N, Einenkel J, et al: Clonal history of papillomavirus-induced dysplasia in the female lower genital tract. J Natl Cancer Inst 97: 1816-1821, 2005.

22. Morris M, Eifel PJ, Lu J, et al: Pelvic radiation with concurrent chemotherapy compared with pelvic and para-aortic radiation for high-risk cervical cancer. N Engl J Med 340: 1137-1143, 1999.

23. Rose PG, Bundy BN, Watkins EB, et al: Concurrent Cisplatinbased radiotherapy and chemotherapy for locally advanced cervical cancer. N Engl J Med 340: 1144-1153, 1999.

24. Keys HM, Bundy BN, Stehman FB, et al: Cisplatin, radiation, and adjuvant hysterectomy compared with radiation and adjuvant hysterectomy for bulky stage IB cervical carcinoma. N Engl J Med 340: 1154-1161, 1999.

25. Whitney CW, Sause W, Bundy BN, et al: Randomized comparison of fluorouracil plus Cisplatin versus hydroxyurea as an adjunct to radiation therapy in stage IIB-IVA carcinoma of the cervix with negative para-aortic lymph nodes: a Gynecologic Oncology Group and Southwest Oncology Group study. J Clin Oncol 17: 1339-1348, 1999. 
26. Pearcey R, Brundage M, Drouin P, et al: Phase III trial comparing radical radiotherapy with and without Cisplatin chemotherapy in patients with advanced squamous cell cancer of the cervix. J Clin Oncol 20: 966-972, 2002.

27. Distefano M, Ferrandina G, Smaniotto D, et al: Concomitant radiochemotherapy plus surgery in locally advanced cervical cancer: update of clinical outcome and cyclooxygenase- 2 as predictor of treatment susceptibility. Oncology 67: 103-111, 2004.

28. Buda A, Fossati R, Colombo N, et al: Randomized trial of neoadjuvant chemotherapy comparing paclitaxel, ifosfamide, and Cisplatin with ifosfamide and Cisplatin followed by radical surgery in patients with locally advanced squamous cell cervical carcinoma: the SNAP01 (Studio Neo-Adjuvante Portio) Italian Collaborative Study. J Clin Oncol 23: 4137-4145, 2005.
29. Lai CH, Chang CJ, Huang HJ, et al: Role of human papillomavirus genotype in prognosis of early-stage cervical cancer undergoing primary surgery. J Clin Oncol 25: 3628-3634, 2007.

30. De Boer MA, Jordanova ES, Kenter GG, et al: High human papillomavirus oncogene mRNA expression and not viral DNA load is associated with poor prognosis in cervical cancer patients. Clin Cancer Res 13: 132-138, 2007.

31. Frazer IH: Prevention of cervical cancer through papillomavirus vaccination. Nat Rev Immunol 4: 46-54, 2004. 